\title{
PREMISES OF GRANTING RELIEFS IN PAYMENT OF TAX LIABILITY
}

\author{
KATARZYNA ŚWIĘCH-KUJAWSKA ${ }^{1}$
}

\begin{abstract}
The paper was devoted to issues related to the premises of granting reliefs in the payment of tax liability. The prime purpose of the study is an in-depth analysis of the conditions of application of the tax preferences in question. The considerations serve to justify the thesis that the main purpose of the application of tax reliefs in the payment of tax liability is to ensure flexibility in the application of tax law. At the same time, the criteria for their application were formulated on the basis of general clauses, which hinders the practical use of this institution. The research used the method of analyzing the legal text and the judicature acquis as well as the tax law doctrine.
\end{abstract}

\section{Keywords}

Tax; tax relief, tax act; tax liability

JEL Classification: E62, K34, K40

\section{Introduction}

The purpose of this paper is to present and analyze the conditions for granting tax reliefs in the payment of tax liability. The structure of the study was adapted to the researched field. The starting point was to present general issues of an introductory nature. Against this backdrop, in-depth discussions were conducted to confirm the basic premise that granting tax reliefs in the payment of tax liability is based on administrative discretion, and the premises of the use of this institution

1 Professor for Financial Law, Chair of Territorial Self-Government Law, Faculty of Law and Administration, University of Szczecin, Poland. Member of Center for Information and Research Organization in Public Finance and Tax Law of Central and Eastern European Countries. Contact email: k.swiech-kujawska@ wpiaus.pl. 
are formulated using general clauses and terms not fully defined, which creates significant doubts in the practical application of these reliefs. For the purpose of conducting research in the indicated scope, the method of analysis of legal acts, the rich case law of administrative courts and the views of doctrine were used. It included study results presented in particular in publications (Redelbach, 1992; Ziembiński, 1989). The state of discussion over the issues of general clauses.

\section{Reliefs in Payment of Tax Liability - Terminological Findings}

The concept of tax reliefs is important for the outlined problem area, and therefore its analysis is indispensable. First and foremost, it should be noted that the legal definition of this term was first introduced into the legal market under the Tax Ordinance Act of 29 August 1997.

According to Art. $3 / 6$ of the aforementioned law, this concept is to be understood as exemptions, deductions, reductions or cuts provided for in the tax law, the application of which results in the reduction of the tax base or the amount of tax, with the exception of the reduction of the tax due by the amount of input tax within the meaning of provisions on goods and services tax, and other deductions forming part of the construction of this tax. In anticipation of further reflection, it should be noted that classifying an exemption as a relief is at least questionable, and one can agree only that its application produces the same or similar effects as those involved in the application of a relief. It is, therefore, possible to appraise the view that tax reliefs within the meaning of the Tax Ordinance Act are tax reliefs sensu largo, which include tax exemptions and tax reliefs sensu stricto (deductions, reductions, cuts) (Nykiel, 1998: 180).

The interpretation of the provision in question should also apply to the scope of the definition contained therein. Its examination leads us to the conclusion that the concept of reliefs defined within it does not cover either the deferment of the tax payment deadline or breaking up the payment into installments (these elements do not result in a reduction of either the tax base or the tax) (Kulicki, 2000: 53). Therefore, the conclusion that the definition of tax reliefs formulated in Art. 3 of the Tax Ordinance Act is applicable only to systemic reliefs, and thus to reliefs which are a structural element of taxation does have ground.

At the same time the legislator entitles Chapter 7a of the Tax Ordinance Act "Reliefs in the payment of tax liability", including in this category: deferment of tax payment deadline or payment of tax in installments, deferment or installment payment of tax arrears together with default interest or interest on unpaid advances on tax, as well as remission in whole or in part of tax arrears, default interest or prolongation fee. 
According to the findings already made, the above reliefs do not fall within the definition of a legal "tax relief". This leads to a direct conclusion that the reliefs referred to in the aforementioned chapter of the Tax Ordinance Act are a separate category from system reliefs.

This allows one to make a general classification of reliefs into so-called system reliefs, within which detailed breakdowns can be performed, and reliefs in the payment of tax liability. The principles and premises of granting them are the subject of in-depth considerations taken in the later sections of this study.

\section{Principles of Granting Reliefs in Payment of Tax Liability}

As noted, tax reliefs constitute a separate category of tax privileges, both in terms of the place of regulation and the rules of application. The direct legal basis for their application is the Tax Ordinance Act, which also defines the rules for granting such preferences. First and foremost, it should be noted that granting tax reliefs in the payment of tax liability is provided through tax proceedings, although the deferral and the redemption themselves are related to the way in which tax liabilities arise and expire. It should be emphasized that the tax procedure is a special type of administrative procedure in which an administrative body is at the same time the body conducting the proceedings and the entity of the material law relation. Its main purpose is therefore to implement the standards of specific tax law. It is stressed that it consists of a whole series of activities of both administration bodies and other participants, aimed at determining the tax liability and its voluntary settlement. This is at the same time in the broad sense a procedure taking into account the specificity of tax law, such as the self-assessment of tax and the calculation of tax by the payer (Mastalski, 2000: 231).

In the context of the above statements, it is indispensable to cite the definition of tax liability as determining the scope of application of the outlined institution. In the light of the Tax Ordinance Act, the tax liability is taxpayer's liability resulting from the tax obligation to pay tax to the State Treasury, voivodship, county or commune in the amount, within the time limit and at the place specified in the tax law. The specifics of this must involve the taxpayer, the amount of the performance (tax), the date and place of payment. Accordingly, the tax liability is most often referred to as the specification of the tax obligation. In such a sense, it should be assumed that this is a secondary concept, "outflowing" from the tax obligation, constitutes its normative consequence, i.e. the arising of tax liability is a consequence of facts, having a legal significance, whose source can only be a tax obligation specified in the law (Olszowy, 1997: 22). Because of this, it is particularly important to correctly define tax obligation; defectiveness of this construction may prejudice the 
impossibility of concretizing into a tax liability. This leads to the conclusion that the fulfillment of the conditions specified in the tax law norm (the existence of the indicated facts) is the basis for establishing a relationship which is a tax obligation. Like any legal relationship, it has a specific content. In this case, it is always the duty of a specific tax-related behavior.

In conclusion, it must be noted that the interpretation of the title of Chapter 7a of the Tax Ordinance Act referred to at the beginning and the provisions contained therein indicates that the reliefs in question refer to tax liability, i.e. granting them is only possible in respect of tax obligations already reclassified as a legal relationship of a tax liability. Apart from that, the essential features of the institution in question need to include their application, in principle, upon request. The principle that the tax authority decides on granting a relief on the basis of the so-administrative discretion is fundamental for the outlined subject area. That is why they are sometimes referred to as discretionary reliefs. Therefore, it is indispensable to refer to the issue of administrative discretion. We are faced with it when a legal norm does not unambiguously define consequences but allows the body to make choices, leaving a considerable degree of freedom in defining them. This amounts to the establishment of a norm's legal effect by an administration body (Mincer, 1976: 63). In other words, it is combined with the granting to an administrative body the capacity to shape a legal position of the addressee of the norm through specific legal acts, in particular, the administrative act (Nowacki, 1986: 40).

It should be emphasized that a discretionary decision is one that the legislature itself clearly recognizes as such (Filipek, 1997: 47-48). In practice, granting a body the authority to use the institution in question is expressed in the words "the body may". It is also significant to define the scope of the freedom of action of a body using specific types of directives. These are guidelines for the body making the decision. Their common feature is that they are para-legal or non-legal rules, and when formulating them, the legislator usually uses undefined phrases or general clauses ${ }^{2}$. It should also be stressed that in any case of the application of administrative discretion the body must take into account the rules of conduct established by the relevant provisions (Ochendowski, 1997: 132), e.g. tax procedure from the Tax Ordinance Act, such as the principle of reasoning, trust. It should also be noted that the judicial review of discretionary decisions is limited and boils down to an assessment whether the deciding authority has investigated the issue in terms of statutory directives as well as whether it collected and considered all the evidence in the case (Voivodship Administrative Court: I SA/Lu 944/12, Voivodship Administrative Court: I SA/Po 315/15). On the other hand, the misapplication of a provision as the legal basis for a decision, where there is a rule of law giving rise to 
a decision, does not constitute such defectiveness which would justify reversing the decision (Supreme Administrative Court: SA/Wr 3095/95).

\section{Premises of Granting Discretionary Reliefs}

Granting one of the reliefs in the payment of tax liability requires, as has already been emphasized, the conduct of tax proceedings, which are not of a particular nature or distinct from other proceedings covered by the regulations of the Tax Ordinance Act. The subject of this procedure is the attribute (Brolik, 2012: 40). Employing the institution of administrative discretion means that the tax authority may but does not have to issue a positive decision, i.e. the application of the relief established within it is a right and not a duty of the tax authorities. The authority, however, is not exempted from the obligation to carry out complete and precise findings of fact and to assess whether the circumstances of the case correspond to the conditions for granting the relief sought. When justifying the discretionary decision, the authority must provide clear and convincing arguments both as regards facts and law. Recognizing that the party is in a situation where it is possible to grant a relief under the procedure indicated in the law, the authority is obliged to explain reasonably why, under administrative discretion, it refuses to grant it or grants it in the amount lower than expected by the party (Supreme Administrative Court: OSK 1334/14). Basically, as already indicated, this procedure is initiated by the taxpayer's request, and for business entities, additional conditions for granting tax preferences have been introduced.

However, for the subject area under discussion, premises of granting one of the reliefs in the payment of tax liability indicated at the outset are of fundamental importance. According to Art. 67a of the Tax Ordinance Act the tax authority may grant a relief in cases justified by an important interest of the taxpayer or of the public interest. As it clearly results from this, the assurance of flexibility in the application of tax law is to be served by the use of undefined phrases and general clauses. It should be noted here that in the provision referred to the clause was placed first and only then a vague phrase was used. Doing so impacts a high degree of flexibility of the text (Borszowski, 2017: 172).

As already mentioned, the premises of granting reliefs in the payment of tax liability are formulated using vague terms and general clauses. Because of their function, general clauses should be the subject of theoretical analysis. First of all, it should be emphasized that they are treated as one of the groups of undefined phrases, which, among others, prejudges the fact that they also fall under means of achieving flexibility of the law. They are, at the same time, a frequently used means by which directives for the authority exercising the law are formulated, 
specifically for the body Authorized to use the decision-making freedom (they affect the scope of this freedom). According to L. Leszczyński, general clauses allow the content of the law to be opened, which is to be understood as transferring part of the responsibility for the content of the law from the bodies that constitute them - to the authorities exercising the law. This is due to the extension of the share of legal practice, which makes decisions on the application of the law, also on the basis of the criteria indicated in these clauses, in determining the content of the law being created (Leszczyński, 2000: 4). The common (and not controversial) feature of views formulated by the science is a statement that general clauses contain a reference to a normative system separate from the law (Wójcik, 1987: 124) (nonlegal system).

It is also generally assumed that these clauses are related to all cases in which the authority exercising law derives its authority to be directed not only by the content of positive law based on written sources (legal texts) or possibly binding precedents on the ground of sufficiently developed doctrine, but also by some evaluations or non-legal directives, whose character is often the subject of ongoing litigation (Ziembiński, 1989: 14).

It should also be noted that in the literature there is no clearly formulated definition of the clauses under discussion. It is, however, desirable to present their representative terms. According to the first definition of general clauses, contained in the Small Encyclopedia of Law of 1959, a general clause is a legal provision that aims to achieve flexibility in the application of law by the use of general concepts subject to the assessment of the authority exercising (Dąbkowski, 1960: 235). T. Zieliński acknowledged the fact that it is not limited to specifying the defined concept but also points out what the function of a provision (phrase) constituting a general clause is (it seeks to achieve flexibility in the application of the law). The metaphorical word "flexibility" is not a juridically precise phrase (Zieliński, 1988: 35). On account of that, the Author proposed that general clauses be defined as non-specific phrases referring to extra-legal rules and assessments that allow the authorities exercising the law to decide on the application of the rules in force and thus to treat each case individually. According to this concept, general clauses include both phrases containing direct references to extra-legal rules (norms), as well as phrases and expressions that have different "denotations" depending on the assessment used by interpreters in specific situations (Zieliński, 1988: 56). Diversification of these assessments allows for individual treatment of each case.

In turn, given the role of general clauses in the legal text, two types of general clauses were distinguished: 
1) Classic general clauses - which consist in giving the authority exercising the law the capacity to exercise individual judgments of a particular situation or certain principles of conduct of axiological justification, not formulated in the law, when deciding on particular cases (Redelbach, 1992: 260). In this case, reference may be made to certain extra-legal standards, extra-legal rules of conduct, i.e. directives of a general nature.

An assumption needs to be made here that an orderly system of values, evaluations, and norms to which reference is possible is valid. It also does not mean that it is not evolutionary, but it is sufficient that it is stable enough to be helpful (constitute the basis) for certain determinations. One of the roles of the legislator, in this case, is to closely monitor the changes taking place, so that, if necessary, appropriate amendments in the legal regulation are made.

On the one hand, this allows the flexibility of the law to be maximized as the body has the power to individualize the decisions being made, but on the other hand, there is a danger of inconsistency in the decisions taken by the authority. In practice, leaving the body with complete freedom of judgment could lead to the absence of any control and to the arbitrariness of the decisions taken too far.

2) Functional general clauses - related to the deliberate introduction of undefined terms into the text of legal acts, the interpretation of which every time is most frequently associated with the evaluative issue of the authority exercising the law (Redelbach, 1992: 260).

At this point in the study, it is appropriate to analyze the general clauses used by the legislator in the aforementioned Art. 67a of the Tax Ordinance Act. The existence of an important interest of the taxpayer or of the public interest is a necessary condition for a favorable consideration of the taxpayer's request while being subject to the assessment of the tax authority. The terms "taxpayer's interest" and "public interest" play a key role. In the first place, it should be noted that legal science deals more with explaining the role of the concept of interest in lawmaking and the application of law rather than defining it (Presnarowicz, 1998: 31).

However, it is pointed out that the term "interest" can be understood as "a state of a certain tension that ceases at the moment of satisfying the interest or the relationship arising between man and something conceived or existing as a result of desiring this thing by man". "Good", serving to satisfy the interest, is usually distinguished from the interest (Lang, 1997: 129-130).

The clustering itself of the word "interest" with the words "public" or "taxpayer's" means that they are completely different categories. When referring to the public interest, what is pointed to is the manner in which it is expressed and what is 
relevant here is the fact that all the findings are of a general nature. Individual interest, however, is identified with the sphere of powers, needs, or values perceived by a particular subject who refers to them or to whom it is referred (Orłowski, 2000: 96).

One can conclude from this that the interest of the taxpayer will involve the desire to preserve the benefits (values) already in hand or the state of waiting for a new good (Presnarowicz, 1998: 30). There is no obstacle than to perceive it as a relation between an objective state and an evaluation of that state from the point of view of the benefits it does or may bring to the individual (Lang, 1997: 139). The legislator also exposes the gradation of "interest", which must be "important" to allow preferential treatment of the person presenting that interest. The term "public interest" is most often associated with the fact of socialization of an individual and is sometimes perceived as a result of individual interests (Zdyb, 1993: 298). It is permissible to talk about it as the interest of the state representing all its citizens. There is often conflict between the private interest and the public interest, and it is, therefore, essential to work out a certain type of compromise. This is all the more difficult when it comes to "the consensus between values symbolizing individual freedoms and values that symbolize certain necessities conditioning public order" (Zdyb, 1993: 302).

It is concluded that the precise distinction between the "important interest of taxpayers" and the "legitimate public interest" is at times impossible in practice, sometimes the same premises can be the basis for referring to one of these "interests" when the latter are equated. In view of the above, it cannot be accepted that tax authorities are required to settle cases taking into account the taxpayer's important interest unless precluded by public interest - by which the tax authority seems to understand the interest of the state budget. The conjugate "or" as used in the Tax Ordinance Act denotes a possibility of exchange which entails that both of these conditions are of equal character (Supreme Administrative Court: I SA/Lu 1770/98; Supreme Administrative Court: II FSK 510/11).

The natural consequence of the use of general clauses in the content of the Tax Ordinance Act as regards granting tax reliefs in the payment of tax liability is to interpret the conditions for the application of these reliefs by the authorities exercising the law. It is characteristic that a certain attempt to systematize the notions is made by the judicature. The case law of administrative courts in this area is extremely rich. Its analysis allows for further findings. First and foremost, it has been signaled that the condition of "the taxpayer's important interest" requires the determination of the financial and material situation of the party and the economic effects that would arise as a result of fulfilling the obligation, since the existence of an important interest of the applicant is not determined by the subjective conviction 
of the party. The term "public interest" is to be understood as a directive for conduct which requires taking account of the respect of the entire society's common values such as: justice, equality, security, citizens' confidence in the authorities, the efficiency of action of the state apparatus, correcting wrong decisions as well as a situation where the payment of tax liability results in the taxpayer's need to seek state aid measures. When examining the case, the authority should also each and every time determines what is more advantageous from the point of view of the public interest (pursuing claims or application of relief) (Voivodship Administrative Court: I SA/Gd 362/17; Voivodship Administrative Court: I SA/Sz 1063/16).

It is therefore justified to state that the evaluative nature of the directives has a significant impact on judicial decisions in which these conditions are specified. In a rather uniform pattern of deciding, it is assumed that the taxpayer's important interest involves a situation where, due to extraordinary, random circumstances, the taxpayer is not in a position to pay tax arrears. It will be the loss of opportunity to earn money, loss of property. On the other hand, the public interest means a situation where the payment of tax arrears will require the taxpayer to seek state aid because he will not be able to meet his material needs (Supreme Administrative Court: SA/Sz 850/98).

Accordingly, the granting of a relief is justified in those cases which have been caused by factors which the taxpayer has no influence on and which are independent of the manner of his conduct (Supreme Administrative Court: III SA 372/99, as well as Supreme Administrative Court: I SA/Kr 983/98, Supreme Administrative Court: I SA/Lu 1485/98). Not only emergency situations, but also a regular economic situation, the amount of income earned and expenditure incurred by the party should be taken into account (Voivodship Administrative Court: I SA/Op 111/17; Supreme Administrative Court: I FSK 31/08; Supreme Administrative Court: II FSK 1134/15).

In this respect, one of the rulings is characteristic where it was specified that even a serious illness of a taxpayer and his wife, which qualifies as taxpayer's important interest, is not sufficient to grant a relief in the form of a remission of tax. It is necessary to analyze the material situation of the party (Voivodship Administrative Court: I SA/Po 1281/16). This implies an assessment of the real material situation of the taxpayer, which affects the existence of a condition for granting a relief, even though not exhaustive of the term "taxpayer's important interest".

In conclusion, the terms "important interest of the taxpayer" and "public interest" are to be referred each and every time to the specific situation of the taxpayer in the course of tax proceedings, reflecting theoretical assumptions underlying the use of the institution of general clauses. 


\section{Conclusions}

The primary, although not the sole, function of taxes is the fiscal function. Regulations of the general part of tax law serve to feed the state budget and the budgets of local government units with tax revenues. In practice, unconditional enforcement of tax liability could, however, lead to a violation of legally protected values. Hence, it was necessary to ensure flexibility in the application of the levy law. Institutions of protection of interests of taxpayers include among others reliefs based on administrative discretion, which leaves the tax authority with a wide margin in decision-making. Even if the statutory conditions are met, the authority may refuse to grant the privilege to the applicant.

The legal basis for the use of reliefs in the payment of tax liability is set out in the Tax Ordinance Act, which suggests that the introduction of legal regulations in an act of a general nature gives the possibility of applying them to all currently applicable taxes. Only the rules for handling them with regard to taxpayers conducting business activity were defined in a more rigorous way. In the legal structure of the institution in question, general clauses and vague phrases have been used whose practical use has given rise to a number of interpretative doubts. Irrespective of this, the adoption of such a solution should be assessed as unequivocally positive. Allowing tax authorities to make decisions with some freedom makes it possible to individualize the tax burden, which is extremely important, especially in intrusive tax law.

\section{References}

Bogucka, I.: Państwo prawne a problem uznania administracyjnego (Rule of law and the problem of administrative discretion), Państwo i Prawo (State and Law) no. 10 (1992).

Borszowski, P.: Określenia nieostre i klauzule generalne w prawie podatkowym (Vague terms and general clauses in tax law), Warszawa: Wolters Kluwer, 2017.

Brolik, J.: Postępowanie podatkowe w przedmiocie ulg w spłacie zobowiązań podatkowych $\mathrm{z}$ art. $67 a \S 1$ ordynacji podatkowej (Tax proceedings in the scope of reliefs in the payment of tax liability pursuant to Article 67a $\$ 1$ of the Tax Ordinance Act), Przegląd Podatkowy (Tax Review) no. 8 (2012).

Dąbkowski, S. (ed.): Mała Encyklopedia Prawa (Small Encyclopaedia of Law), Warszawa: PWN, 1960.

Filipek, J.: W sprawie uznania administracyjnego (On administrative discretion), Przegląd Prawa i Administracji (Law and Administration Review) vol. XXXVIII (1997).

Kulicki, J.: Konstytucyjne podstawy nakładania podatków (Constitutional basis for levying taxes), Prawo Spółek (Company Law) no. 3 (2000). 
Lang, J.: Z rozważań nad pojęciem interesu w prawie administracyjnym (Considerations on taking up interest in administrative law), Przegląd Prawa i Administracji (Law and Administration Review) no. 38 (1997).

Leszczyński, L.: Funkcje klauzul odsyłających a model ich tworzenia w systemie prawa (Functions of referring clauses and the model of their creation in the system of law), Państwo i Prawo (State and Law) no. 7 (2000).

Mastalski, R.: Prawo podatkowe (Tax law), Warszawa: C.H. Beck, 2000.

Mincer, M.: Pojęcie uznania administracyjnego (The concept of administrative discretion), Państwo i Prawo (State and Law) no. 3 (1976).

Nowacki, K.: Kontrola decyzji opartych na uznaniu administracyjnym (Review of decisions based on administrative discretion), Wrocław: Uniwersytet Wrocławski, 1986.

Nykiel, W.: Zwolnienia i ulgi podatkowe a konstrukcja podatku (wybrane zagadnienia) (Tax exemptions and reliefs and the structure of tax (selected issues)), in: Brzeziński, B. et al.: Księga pamiątkowa ku czci Profesora Apoloniusza Kosteckiego. Studia z dziedziny prawa podatkowego (Professor Apoloniusz Kostecki's commemorative book. Studies in the area of tax law), Toruń: TNOiK Dom Organizoatora, 1998.

Ochendowski, E., Prawo administracyjne (Administrative law), Toruń: TNOiK Dom Organizatora, 1997.

Olszowy, W.: Decyzja podatkowa, podejmowanie i kontrola (Tax decision. Taking and review), Warszawa: KiK, 1997.

Orłowski, J.: Przesłanki umorzenia zaległości podatkowych w ordynacji podatkowej (Conditions for writing off tax arrears in the Tax Ordinance Act), Radca Prawny (Legal Adviser) no. 4 (2000).

Presnarowicz, S.: Zwolnienia i ulgi uznaniowe - przesłanki rozstrzygnięć (Discretionary exemptions and reliefs - conditions for decisions), Przegląd Podatkowy (Tax Review) no. 7 (1998).

Redelbach, A. et al: Zarys teorii państwa i prawa (Outline of the theory of state and law), Warszawa: PWN, 1992.

Wójcik, K.: Klauzule generalne jako odesłanie pozasystemowe (General clauses as non-system, referral), Acta Universitatis Lodziensis no. 32 (1987).

Zdyb, M.: Interes jednostki a interes publiczny (społeczny). Konflikt interesów (Individual interest and public (social) interest. Conflict of interests), Zeszyty Naukowe Uniwersytetu Marii Curie-Skłodowskiej w Lublinie (Scientific Papers of the Maria Curie-Skłodowska University in Lublin) no. 31 (1993).

Zieliński, T.: Klauzule generalne w prawie pracy (General clauses in labour law), Warszawa: PWN, 1988.

Ziembiński, Z.: Stan dyskusji nad problematyką klauzul generalnych (The state of discussion over the issues of general clauses), Państwo i Prawo (State and Law) no. 3 (1989).

PL: Tax Ordinance Act of 29 August 1997. 
PL: Supreme Administrative Court: SA/Wr 3095/95.

PL: Supreme Administrative Court: SA/Sz 850/98.

PL: Supreme Administrative Court: I SA/Lu 1485/98.

PL: Supreme Administrative Court: I SA/Kr 983/98.

PL: Supreme Administrative Court: III SA 372/99.

PL: Supreme Administrative Court: I SA/Lu 1770/98.

PL: Supreme Administrative Court: I FSK 31/08.

PL: Supreme Administrative Court: II FSK 510/11.

PL: Supreme Administrative Court: II FSK 1134/15.

PL: Voivodship Administrative Court: I SA/Lu 944/12.

PL: Voivodship Administrative Court: I SA/Po 315/15.

PL: Voivodship Administrative Court: OSK 1334/14.

PL: Voivodship Administrative Court: I SA/Po 1281/16.

PL: Voivodship Administrative Court: I SA/Op 111/17.

PL: Voivodship Administrative Court: I SA/Sz 1063/16.

PL: Voivodship Administrative Court: I SA/Gd 362/17. 